\title{
A DISPENSA DE AVERBAÇÃO DA RESERVA LEGAL NO REGISTRO DE IMÓVEIS: DIMINUIÇÃO DA PROTEÇÃO AMBIENTAL?
}

\section{THE DISPENSE OF LEGAL RESERVE IN THE REGISTRATION OF PROPERTY: DECREASE OF ENVIRONMENTAL PROTECTION?}

\author{
Thiago de Miranda Carneiro ${ }^{1}$ \\ Edson Roberto Siqueira Jr. ${ }^{2}$
}

\section{RESUMO}

Pretende-se a análise do cadastro ambiental rural (CAR) e a dispensa da averbação da reserva legal (RL) com fundamento na Lei $\mathrm{n}^{\circ} 12.651 / 12$. Serão abordados elementos da proteção ambiental e da propriedade imobiliária para tratar da revogação de averbação da reserva legal no registro de imóveis e sua inserção no CAR, bem como o papel do registro de imóveis e a publicidade registral no intuito de averiguar a segurança jurídica no tráfego imobiliário. Utilizou-se método exploratório por meio de análise bibliográfica e documental iniciando no direito constitucional e ambiental passando pelo direito registral.

Palavras-chave: Cadastro Ambiental Rural; Meio ambiente; Propriedade Imobiliária; Registro da Propriedade; Reserva Legal.

\begin{abstract}
It is intended to analyze the rural environmental registry and exemption from the registration of the legal reserve on the basis of Law 12.651/12. They will be addressed elements of environmental protection and real estate to handle the revocation of registration of the legal reserve in real estate registry and their inclusion in the CAR, as well as property registration paper and registral advertising in order to ascertain the legal traffic safety real estate. We used exploratory method through literature and document analysis starting at the constitutional and environmental law through the registral law.

\footnotetext{
${ }^{1}$ Mestrando em Direito Ambiental e Desenvolvimento Sustentável pela Escola Superior Dom Helder Câmara, Belo Horizonte, Minas Gerais, (Brasil). Mestrando em Direito Privado pela FUMEC, Belo Horizonte (Brasil).

${ }^{2}$ Mestrando em Direito Ambiental e Desenvolvimento Sustentável pela Escola Superior Dom Helder Câmara. Belo Horizonte, Minas Gerais, (Brasil). Especialista em Direito Público pela Fadivale e Direito Tributário pelo IBET, Indústria Brasileira de Equipamentos Térmicos, São Paulo (Brasil).

E-mail: edsonsiqueirajr@ hotmail.com
} 
Keywords: Rural Environmental Registry; Environment; Real Estate Property; Registration of Property; Legal reserve.

\section{INTRODUÇÃO}

O presente estudo faz uma análise do cadastro ambiental rural (CAR) e a dispensa da averbação da reserva legal (RL) conferida pela nova Lei Florestal n 12.651/12.

Também analisa o sistema de registro de imóveis e seus institutos com o exame da possibilidade de informações ambientais no atendimento à função social da propriedade e preservação do meio ambiente.

O registro de imóveis surgiu como mecanismo para controle do direito de propriedade e como instrumento de segurança jurídica para o tráfego imobiliário. Por outro lado, em virtude da constante evolução do direito ambiental e consequente inclusão da função social no conceito de propriedade, fez-se necessário o estudo das novas características do registro de imóveis, mormente, a premência da aplicação das normas de proteção ambiental e utilização de sua estrutura para tal finalidade.

Para tanto, inicialmente serão demonstrados elementos do direito ambiental e da propriedade imobiliária como conceitos primordiais à análise do tema, notadamente meio ambiente, direito ambiental, reserva legal e cadastro ambiental rural, para ao final tratar da revogação de averbação da reserva legal no registro de imóveis e sua inserção no cadastro ambiental rural, bem como o papel do registro de imóveis e a publicidade registral no intuito de averiguar a segurança jurídica no tráfego imobiliário e o papel do registrador no fornecimento de informações sobre cada imóvel em atendimento à função social da propriedade e preservação do meio ambiente, tudo, em busca da sadia qualidade de vida para as atuais e futuras gerações.

Para atingir dos objetivos colimados utilizou-se o método exploratório por meio de análise bibliográfica e documental iniciando no direito constitucional e ambiental, além direito registral. 


\section{A PROTEÇÃO DO MEIO AMBIENTE NO BRASIL}

Durante longo período os humanos não se preocupavam com a preservação e proteção dos recursos naturais em virtude da abundância, entretanto, com o advento do desenvolvimento científico e o aumento acelerado da população mundial ocorrido após a revolução industrial do século XVIII, foi possível perceber graves consequênciais às reservas de recursos naturais decorrentes das atividades e tecnologias empregadas no processo desenvolvimentista (PORTO-GONÇALVES, 2015).

Nesta esteira, foram organizados movimentos esparsos em defesa do meio ambiente no mundo, porém, entre os dias 5 e 16 de junho de 1972, foi realizada pela Organização das Nações Unidas (ONU), na capital da Suécia, Estocolmo, a Conferência das Nações Unidas sobre o Meio Ambiente Humano (United Nations Conference on the Human Environment), também conhecida como Conferência de Estocolmo, tratando-se da primeira grande conferência realizada para debater sobre a relação entre o homem e o meio ambiente.

Importante perceber que os movimentos pré Conferência de Estocolmo contiveram indagações em relação aos modelos de desenvolvimento ocidentais e socialistas.

Na América do Norte, especialmente nos Estados Unidos na década de 60, ocorriam diversas manifestações tendo em voga os direitos civis, assim como a Guerra do Vietnã. Na Europa ocidental em 1968, via-se uma geração mais opositora à ideia de um regime fechado. (LAGO, 2007).

Neste mesmo contexto de reivindicações, surgiram, também, grupos da classe média dos países ricos em prol da preservação do meio ambiente, tendo em vista a degradação causada pela industrialização nesses países desde 1950, bem como a ocorrência de algumas catástrofes ambientais.

A necessidade de debater sobre temas ambientais se fazia latente, eis que diversos países já detectavam que alterações ambientais sérias estavam ocorrendo em várias partes do mundo, como, por exemplo, secas em lagos e rios, inversões térmicas e ondas de calor. O homem começava a perceber que o meio ambiente não era uma fonte inesgotável de exploração de recursos. 
Em 1968 um grupo de cientistas, nominado "Clube de Roma", reuniu-se e travou discussões acerca dos problemas ambientais publicando estudo, chamado de "Os limites do crescimento", no qual o grupo fez projeções matemáticas acerca dos efeitos que estariam por vir em relação aos danos causados ao meio ambiente com fundamento no crescimento descontrolado da população, a industrialização, a poluição e o consumo desenfreado dos recursos ambientais. De acordo com Franz Bruseke (1994), as projeções eram essencialmente alarmistas, mas contribuíram para conscientizar a população.

Assim, diante da preocupação com o meio ambiente e das projeções catastróficas, a Organizações das Nações Unidas (ONU), juntamente com 113 países, além de mais de 400 instituições governamentais e não governamentais, realizou a primeira Conferência Mundial sobre o Homem e o Meio Ambiente em Estocolmo, capital da Suíça, em 1972, quando temas como chuva ácida e o controle da poluição do ar foram intensamente debatidos.

A conferência ficou marcada por calorosas discussões, principalmente entre os que pugnavam pelo desenvolvimento a qualquer custo para sair da pobreza e aqueles que queriam o desenvolvimento sustentável, com o fito de que a natureza se recuperasse, já que não eram pobres.

Estudos contendo dados técnicos, perícias, laudos, bem como dezenas de discursos foram apresentados durante a conferência, tanto por parte dos que queriam a estagnação dos danos causados ao meio ambiente, quanto por parte dos que pugnavam pelo desenvolvimento a qualquer custo, sendo, ao final, elaborado documento denominado de "limites para o crescimento".

A conferência de Estocolmo foi um marco no que se refere ao reconhecimento do meio ambiente como meio necessário ao desenvolvimento humano sadio e adequado, tendo direcionado suas deliberações sobre a poluição atmosférica e sobe a intensa exploração dos recursos naturais para todo o mundo, algo inédito na forma como apresentada, sempre com a intenção de possibilitar a relação harmônica entre o homem e o meio ambiente.

Com o fim da Conferência de Estocolmo e elaboração do texto final, diversas Constituições por todo o mundo, que até então não dispunham sobre a temática ambiental, começaram a trazer previsões em seus textos, algumas superficiais outras amplamente registradas em vários artigos. 
As Constituições latino-americanas tiveram grande influência por parte da Conferência de Estocolmo, tendo em vista as características encontradas nos países da região e o cenário político vivido de cada um deles. Em muitos países da região, a necessidade de mudanças sociais e políticas se faziam necessárias.

Assim, diante da necessidade de mudanças constitucionais, bem como da eclosão do tema ambiental no mundo, o constitucionalismo latino-americano passou a inserir a temática em questão em seus textos.

“Um terceiro elemento para análise indica que o tema ambiental fora inserido nas constituições da região também pela grande dependência das economias aos recursos ambientais ${ }^{3}$ ", (SANTOS, 2008, p. 02).

No Brasil, as questões ambientais tiveram destaque a partir da Lei $n^{\circ}$ 6.938/81 denominada Política Nacional de Meio Ambiente que tratou de conceituar o meio ambiente no art. $3^{\circ}$, I, daquela Lei.

Conceitua, portanto, o meio ambiente de modo abrangente, tendo em vista que o artigo faz "uma relação do meio ambiente com a natureza como um todo, de forma que integra e interage com todos os seus elementos'(MACHADO, 2010, p. 68).

A partir de então, houve a ingerência do direito em matéria ambiental para proteger o meio ambiente e a sociedade como todo, consolidando-se no Brasil o direito ambiental "como um instrumento regulador das relações sociais com a natureza e a economia" (WEBER, 2014, p.120).

\section{A PROPRIEDADE IMOBILIÁRIA}

$\mathrm{O}$ direito de propriedade é um direito fundamental garantido no art. $5^{\circ}$, caput e inciso XXII da Constituição Federal de $1988^{4}$.

\footnotetext{
${ }^{3}$ Tradução dos Autores. Texto original: Un tercer elemento de análisis nos indica que la riqueza en recursos naturales de la Región, y la estrecha dependencia de sus economías respecto de esos recursos.

${ }^{4}$ Art. $5^{\circ}$ Todos são iguais perante a lei, sem distinção de qualquer natureza, garantindo-se aos brasileiros e aos estrangeiros residentes no País a inviolabilidade do direito à vida, à liberdade, à igualdade, à segurança e à propriedade, nos termos seguintes: $[\ldots]$ XXII - é garantido o direito de propriedade; (BRASIL, 1988).
} 
Assim, ao proprietário é facultado o direito de usar, gozar, usufruir e dispor de sua propriedade, e de reavê-la, de quem a esteja possuindo injustamente.

O direito de usar (jus utendi) reflete a possibilidade do proprietário poder se servir da propriedade e utilizá-la da forma que bem entender, contanto, que não cause prejuízos alheios; já o direito de usufruir (jus fruendi), consiste na possibilidade do proprietário poder retirar os frutos concebidos por sua propriedade; por sua vez, o direito de dispor da coisa (jus abutendi), refere-se ao fato do proprietário poder transferir ou alienar a propriedade a terceiros; e por fim, o direito de reaver a propriedade (rei vindicatio), diz respeito ao direito que o proprietário tem de poder reivindicar a sua propriedade que está em poder de outrem injustamente.

Há duas principais teorias que fazem uma análise da essência do direito de propriedade, quais sejam: a teoria da pertença de cunho qualitativo e a teoria do domínio de cunho quantitativo.

A primeira teoria trata de uma situação de pertencimento de determinado bem por um indivíduo, criando-se dessa forma, uma relação de subordinação do bem ao titular do direito; por seu turno, a segunda teoria diz-se quantitativa porque engloba inteiramente a propriedade ao seu titular, lhe dando vastos poderes sobre a coisa.

Para Luís Carvalho Fernandes (2009, p. 334), o direito de propriedade representa "o direito real máximo, mediante o qual é assegurada a certa pessoa, com exclusividade, a generalidade dos poderes de aproveitamento global das utilidades de certa coisa", entretanto, observa-se que tal definição é alicerçada apenas na ideia dos poderes que o proprietário tem sobre sua propriedade, ostentando-se uma concepção individualista da propriedade surgida no Direito Romano e reproduzida no Código Civil Brasileiro de 1916.

Com o passar dos anos a concepção do direito de propriedade evoluiu, saindo de uma perspectiva liberal individualista em que atendia única e exclusivamente aos interesses do proprietário, para ganhar novos contornos na atualidade, com o atendimento às necessidades da coletividade buscando-se uma função social e impondo a seu titular, ou seja, o proprietário, uma série de restrições ou limites. 
A função social da propriedade, portanto, determina que o direito de propriedade deva ser utilizado de forma útil, concorrendo para o bem comum, em razão de que a terra improdutiva é prejudicial a toda sociedade (CASTILHO, 2015).

Nas palavras de Ignacio Pereña Pinedo:

Função social da propriedade é um conceito jurídico indeterminado variável ao longo do tempo e deve ser definido pelo legislador [...] é muito mais amplo do que a simples privação do direito [...] configura o exercício e conteúdo de direitos de propriedade. (PINEDO, 2005, p 179-80). ${ }^{5}$

Assim, a Constituição Federal de 1988 dispôs que "a propriedade atenderá a função social"' (art. $5^{\circ}$, XXIII da CRFB/88). Com isso o direito de propriedade será realizado dentro dos limites da lei, ficando os proprietários ou posseiros obrigados a respeitarem as normas e regulamentos administrativos.

Igualmente, o artigo 170, inciso III da Constituição Federal de 1988, indica a função social da propriedade com um princípio fundamental da economia, impondo restrições à atividade empresarial.

Portanto, ao direito de propriedade caberá a aplicação do princípio da função social, uma vez que "a propriedade não é direito subjetivo do proprietário, mas a função social do detentor da riqueza, pelo que deve gerir a coisa tendo em vista não só o seu melhor rendimento, como também o interesse da coletividade"' (HARADA, 2006, p. 5).

Outros dispositivos constitucionais também fazem referência à função social, como o artigo 182 que trata da função social da cidade e prevê que o plano diretor é o instrumento básico da política de desenvolvimento e de expansão urbana, determinando sanções no caso de descumprimento da função social.

A posição da função social da propriedade nos referidos dispositivos indica que a propriedade deve andar sempre ao lado da função social de modo a atender toda a coletividade.

\footnotetext{
5 Tradução dos Autores. Texto original: [...] la función social de la propiedad es un concepto jurídico indeterminado, variable en el tiempo, y que deberá ser definido por el legislador [...] es un concepto mucho más amplio que la simple privación del derecho [...] configura el ejercicio y el contenido del derecho de propiedad. PINEDO, Ignacio Pereña. La función social del derecho de propiedad. In: Propiedad y derecho constitucional. Coord. Francisco J. Bastida. Madrid: Colegio de Registradores da España, 2005.
} 
Lado outro, ao se falar em função socioambiental da propriedade, diz-se que cabe ao proprietário de um bem o dever de exercer o seu direito de propriedade não apenas em seu próprio interesse, mas em benefício da coletividade.

Para Patryck de Araújo Ayala (2012, p. 300):

\begin{abstract}
O princípio da função socioambiental da propriedade superpõe-se à autonomia privada que rege as relações econômicas para proteger os interesses de toda a coletividade em torno de um direito ao meio ambiente ecologicamente equilibrado. Somente a propriedade que cumpra a sua função social possui proteção constitucional. Por essa razão, seu descumprimento importa a imposição de uma sanção: a desapropriação. Esta é suportada pelo proprietário exatamente em razão do exercício irresponsável do direito e da gestão inadequada dos recursos naturais.
\end{abstract}

Assim, o proprietário tem o dever de exercer o seu direito de propriedade em conformidade com a preservação da qualidade ambiental, e caso não faça, o exercício do seu direito de propriedade será ilegítimo, momento em que poderá ocorrer desapropriação.

Sobre o tema, Carlos Frederico Marés (2003, p. 134) ensina que:

[...] a terra, nos sistemas jurídicos do bem-estar social deve cumprir uma função social que garanta os direitos dos trabalhadores, do meio ambiente e da fraternidade. A obrigação de fazê-la cumprir é do titular do direito de propriedade que perde os direitos de proteção jurídica de seu título caso não cumpra, isto é, ao não cumprir não pode invocar os Poderes do Estado para proteger seu direito. Dito de outra forma, não há direito de propriedade para quem não faz a terra cumprir sua função social.

Não obstante, em virtude das influências sociais, econômicas e ambientais manifestadas no direito de propriedade Edésio Fernandes (2006, p. 15) aponta que "não se pode mais reduzir a noção de função socioambiental da propriedade meramente à ideia de limitações administrativas externas ao exercício do direito".

Pode-se perceber, portanto, que o conceito de propriedade evoluiu com o Estado Democrático de Direito para incluir em si a função social, sem a qual não há direito de propriedade.

\title{
3.1 A Reserva Legal e o Cadastro Ambiental Rural na Lei Florestal n ${ }^{\circ}$ 12.651/12
}


A Lei $\mathrm{n}^{\circ} 7.803$ de 18 de julho de 1989 alterou a redação da Lei $\mathrm{n}^{\circ} 4.771$, de 15 de setembro de 1965, indicando que a expressão reserva legal, trataria de determinada percentagem de floresta protegida nas propriedades privadas rurais, impondo-se a obrigatoriedade da averbação na matrícula do imóvel, impedindo a alteração da sua destinação em caso de transmissão ${ }^{6}$.

Por sua vez, o artigo $1^{\circ}, \S 2^{\circ}$, III, da Lei $\mathrm{n}^{\circ}$ 4.771/65 antigo Código Florestal, que reserva legal era toda área situada em posse ou propriedade rural, excetuada a de preservação permanente, "necessária ao uso sustentável dos recursos naturais, à conservação e reabilitação dos processos ecológicos, à conservação da biodiversidade e ao abrigo e proteção de fauna e flora nativas" (BRASIL, 1965).

Veja-se que a reserva legal revela-se instrumento de "grande importância na manutenção da qualidade de vida e no equilíbrio ecológico. Objetiva restringir o exercício da posse e da propriedade em delimitadas porções de terra, visando salvaguardar uma conservação mínima do meio ambiente', (D’AVILA, 2015, p. 351).

Conforme enfatiza Mariana de Paula e Souza Renan (2015, p.75) a reserva legal (RL) espelha um dos institutos jurídicos de grande importância para a "política de preservação e conservação florestal no Brasil. Trata-se de limitação administrativa na qual se exige do proprietário rural a manutenção de parcela da propriedade que deverá conter a cobertura de vegetação nativa daquele território".

Observa-se que o $\S 8^{\circ}$ do art. 16 , do da Lei $n^{\circ} 4.77 / 65$, após redação dada pela Medida Provisória $n^{\circ}$ 2.166-67, de 2001 determinava que, a área de reserva legal deveria ser averbada à margem da inscrição de matrícula do imóvel, no registro de imóveis competente.

Como se vê tais dispositivos continham valiosas informações a respeito dos limites da reserva, uma vez que averbação no registro público garantiria publicidade irrestrita, oponível a todos, erga omnis. Tamanha era a importância da averbação da reserva legal no registro de imóveis que o Decreto Federal n 6.686, de 2008 passou a tipificar como infração a omissão em se averbar a reserva legal, prevendo a pena de advertência e multa diária de $\mathrm{R} \$$

\footnotetext{
${ }^{6}$ Art. $16[\ldots] \S 2^{\circ}$ A reserva legal, assim entendida a área de, no mínimo, 20\% (vinte por cento) de cada propriedade, onde não é permitido o corte raso, deverá ser averbada à margem da inscrição de matrícula do imóvel, no registro de imóveis competente, sendo vedada, a alteração de sua destinação, nos casos de transmissão, a qualquer título, ou de desmembramento da área. (BRASIL, 1989).
} 
50,00 a R \$ 500,00 por hectares. O termo final para averbação foi prorrogado várias vezes, por último pelo Decreto n. 7.719, de 2012, que fixou em 11 de junho de 2012 (SANTOS, 2012).

Para obter êxito na averbação, fazia-se necessária a apresentação de diversos documentos pelo interessado, dentre eles: a prévia aprovação do órgão ambiental competente (termo de reserva legal aprovado pela FATMA) e planta assinada pelo engenheiro e proprietários, com anotação de responsabilidade técnica - ART.

Entretanto, depreende-se que a Lei $n^{\circ}$ 12.651/2012 (Nova Lei Florestal) trouxe posicionamento novo ao dispensar averbação da reserva legal à margem da matrícula do imóvel, revogando referidos dispositivos e estabelecendo como necessário, a partir de então, no parágrafo $4^{\circ}$ do artigo 18 , apenas o registro da reserva legal no cadastro ambiental rural CAR, com Redação dada pela Lei no 12.727, de 2012.

Pode-se concluir que a averbação no registro de imóveis, a partir de 2012, é facultativa, pouco servindo à proteção ambiental plena eis que as averbações registrais conferiam publicidade e veracidade, garantindo segurança jurídica aos registros imobiliários de forma que os espaços legais e especialmente protegidos fossem preservados.

O cadastro ambiental rural é um instrumento de auxílio no processo de regularização ambiental de propriedades e posses rurais, revelando-se uma base de dados "estratégica para o controle, o monitoramento e o combate ao desmatamento das florestas e demais formas de vegetação nativa do Brasil, bem como mostra-se um instrumento para planejamento ambiental e econômico dos imóveis rurais" (D’AVILA, 2015, p. 353).

O cadastro ambiental rural foi criado pela Lei $n^{\circ} 12.651 / 12$ e sua regulamentação ocorreu pelo Decreto $\mathrm{n}^{\mathrm{o}} 7.830 / 12$ que criou o sistema de cadastro ambiental Rural - SICAR, objetivando integrar o primeiro cadastro a todas unidades da federação.

Trata-se de registro público eletrônico no qual, obrigatoriamente, todos os imóveis rurais devem ser cadastrados, ficando a inscrição em tal registro, a cargo de órgão ambiental municipal, estadual ou federal. Impõe à União, Estados e ao Distrito Federal, por ato do Poder Executivo, a implantação de programas de regularização ambiental - PRAs, com objetivo de adequação dos imóveis rurais aos termos da legislação. Assim, o cadastro ambiental rural 
torna os processos mais céleres e modernos, ao permitir que os proprietários ou possuidores rurais declarem suas áreas verdes por meio de uma plataforma online.

Em 2014, o Ministério do Meio Ambiente editou a Instrução Normativa $n^{\circ}$ 02, de 05 de maio de 2014, que instituiu o cadastro ambiental no âmbito nacional e determinou o prazo legal de um (01) ano, para adesão dos possuidores rurais e proprietários.

Consoante expõe o Ministério do Meio Ambiente (2012):

O CAR consiste no levantamento de informações georreferenciadas do imóvel, com delimitação das Áreas de Proteção Permanente (APP), Reserva Legal (RL), remanescentes de vegetação nativa, área rural consolidada, áreas de interesse social e de utilidade pública, com o objetivo de traçar um mapa digital a partir do qual são calculados os valores das áreas para diagnóstico ambiental.

Como benefícios do cadastro ambiental rural destacam-se: o de possibilitar o planejamento ambiental e econômico do uso e ocupação do imóvel rural, a inscrição, acompanhada de compromisso de regularização ambiental quando for o caso que é prérequisito para acesso à emissão das cotas de reserva ambiental e aos benefícios previstos nos programas de regularização ambiental - PRA e de apoio e incentivo à preservação e recuperação do meio ambiente, ambos definidos pela Lei 12.651/12.

Mas também há críticas, mormente no que diz respeito ao processo de estabelecimento nacional do sistema, que apresenta fragilidades. Conforme Flavia Camargo (2014) elucida, com o objetivo de simplificar o processo, esse sistema não exige um técnico para a realização do cadastro e autoriza que o produtor rural faça a planta do imóvel delimitando o perímetro e as áreas de conservação utilizando-se da imagem de satélite.

Nesta seara, é factível a possibilidade de inserção de dados errôneos e imprecisos, tendo em vista a dispensabilidade de capacitação técnica que era essencial no regime anterior. Por conseguinte, nota-se que os órgãos ambientais deverão validar todas as informações declaradas possibilitando erros na alimentação dos dados e, em alguns casos, má-fé.

Outra questão que se apresenta é a demora na manifestação do órgão que ensejará a validade temporária dos cadastros gerando insegurança acerca da veracidade das informações prestadas, considerado o grande déficit de fiscalização como a realização de vistorias nos imóveis e solicitação de esclarecimentos. 
Por fim, observa-se que o cadastro ambiental rural ainda não foi implantado em vários estados federados de modo que, nesses, a obrigação de averbação na matrícula do imóvel se mantém.

\section{O PAPEL DO REGISTRO DE IMÓVEIS}

A propriedade imobiliária é objeto do registro de imóveis que é serviço público de organização técnica e administrativa "destinado a garantir a publicidade, autenticidade, segurança e eficácia dos atos jurídicos”, artigo $1^{\circ}$ da Lei n 8.935/1994 (Lei dos Cartórios).

De acordo com Marcelo Melo (2004), o registro de imóveis traz segurança e autenticidade às relações e garante a propriedade de modo relativo.

Todavia, além da proteção do direito de propriedade, o registro de imóveis exerce a função de proteção da função socioambiental da propriedade dando-se publicidade ambiental através dos atos de concentração na matrícula dos imóveis.

Não se pode esquecer que, no moderno Estado Democrático de Direito, não existe propriedade sem o cumprimento da função socioambiental em razão do conceito daquela abarcar esta.

Hodiernamente a função de registrar imóveis é transferida a indivíduos particulares chamados de notários, tabeliões, oficiais de registro ou registradores (art. $3^{\circ}$ da Lei $n^{\circ}$ 8.935/1994), aprovados em concurso público, de provas e títulos, conforme determina o artigo 236 da Constituição Federal de 1988.

Desta maneira, quanto maior a segurança e completude das informações presentes no livro de registros reais e de propriedade, maior a possibilidade de conhecimento sobre a propriedade imobiliária e suas características que se aperfeiçoa com a publicidade registral garantida pela Lei $\mathrm{n}^{\circ} 6.015 / 1973$ (dispõe sobre os registros públicos) e também pela Constituição Federal de 1988, no inciso XXXIII do artigo $5^{\circ}$.

Fernanda de Salles Cavedon (2003, p. 75) explica que a publicidade registral se destina ao cumprimento de três funções:

a) transmite ao conhecimento de terceiros interessados ou não interessados a informação do direito correspondente ao conteúdo do registro; b) sacrifica 
parcialmente a privacidade e a intimidade das pessoas, informando sobre bens e direitos seus ou que lhes sejam referentes, a benefício das garantias advindas do registro; c) serve para fins estatísticos, de interesse nacional ou de fiscalização pública.

Por sua vez, Luiz Guilherme Loureiro (2014, p. 271) registra importante ponto sobre a publicidade registral:

O direito registral imobiliário tem por objeto a publicidade da propriedade de bens imóveis e de outros direitos reais imobiliários, visando a proteção dos titulares de tais direitos reais (publicidade estática) e também a garantia do tráfico jurídico dos bens imóveis (publicidade dinâmica). Destarte, a razão de ser do direito registral é diminuir o risco dos adquirentes de imóveis ou direitos reais a eles relativos, por meio de uma maior segurança jurídica no trafico imobiliário e, consequentemente, diminuindo os custos da transação e contribuindo para a diminuição dos litígios envolvendo imóveis.

Assim, a inscrição no registro de imóveis proporciona a todos os ramos do direito a veracidade e a publicidade concisa para o desenvolvimento de outras relações que necessitam se comunicar com a propriedade imobiliária (cadastro tributário, partilha de bens nas sucessões, penhora ou arresto), sendo certo que nenhum fato relevante ao direito poderá ficar de fora dos registros de imóvel.

Com o direito ambiental a publicidade decorre da própria lei, como no caso de espaços territoriais especialmente protegidos (art. $225, \S 1^{\circ}$, III da CRFB/88) por se tratarem de áreas públicas ou privadas, sujeitas a regime especiais, sobre as quais incidem limitações objetivando a sua proteção.

Não há duvidas de que a finalidade de se averbar a reserva legal é, em especial, dar publicidade para que novos adquirentes de um determinado imóvel tenham conhecimento de sua localização e suas características respeitando-se à finalidade da lei.

Assim, sem o registro imobiliário da reserva legal ambiental, possíveis adquirentes poderão carecer de informações relativas aos imóveis, somente as obtendo por meio dos órgãos públicos competentes.

Sobre a carência de informações relativas aos imóveis, Ingrid Noetzold de Almeida (2016) indaga a respeito da dificuldade de se encontrar informações sobre as limitações ambientais em razão da existência de inúmeros órgãos públicos. 
É relevante, portanto, para a segurança jurídica buscada pelo registro de imóveis, o fornecimento de informações sobre a existência de passíveis ambientais.

No que diz respeito à obrigatoriedade de averbação da inscrição no cadastro ambiental rural na matrícula do imóvel, entende-se que a falta de dispositivo expresso na Lei $\mathrm{n}^{\circ} 12.651 / 12$, não ilide sua obrigatoriedade, em virtude da função socioambiental fazer parte do próprio conceito de propriedade sem o qual, repisa-se, não há propriedade.

Nesse passo, observa-se que a publicidade das informações ambientais, promove segurança jurídica aos registros imobiliários e transparência aos negócios, garantindo-se proteção aos espaços protegidos por lei em conformidade com a função socioambiental da propriedade.

Corroborando com o exposto, Marcelo Augusto Santana de Melo (2010, p.29) destaca que:

\footnotetext{
A CF, ao instituir em cláusula pétrea a função social da propriedade (art. $5^{\circ}, \mathrm{XXIII)}$ e ao declarar que todos têm direito ao meio ambiente ecologicamente equilibrado (art. 225), atribui ao Registro de Imóveis características que outrora não possuía. Dentre elas, está a necessidade de incorporação do conceito de função social da propriedade e do meio ambiente, percepção claramente observada pelo legislador no Estatuto da Cidade e na legislação ambiental.
}

Dessa forma, o registro de imóveis realiza o papel de registrar e fornecer informações sobre cada imóvel em atendimento à função social da propriedade e preservação do meio ambiente, assegurando-se a publicidade registral ambiental em busca da sadia qualidade de vida para as atuais e futuras gerações.

\section{CONSIDERAÇÕES FINAIS}

O presente trabalho procurou analisar a possibilidade de utilização de instrumentos do registro de imóveis como meio eficaz a proporcionar uma proteção ambiental mais efetiva.

Da análise dos elementos de direito ambiental bem como dos instrumentos registrais e notariais, percebeu-se a necessidade de incorporação do conceito de função socioambiental da propriedade no aperfeiçoamento da legislação notarial para que se faça constar todas as 
informações necessárias na matrícula do imóvel referentes a passivos ambientais em razão de integrarem o conceito de propriedade.

A partir do registro tem-se o respeito aos princípios da segurança e da publicidade registral e, também, de potencialização da proteção ambiental, permitindo a qualquer cidadão o direito e o dever de se informar e ser informado. Tudo para concretização da função socioambiental da propriedade.

Por outro lado, observou-se que a Lei $\mathrm{n}^{\circ} 12.651 / 12$ criou o instituto do cadastro ambiental rural fazendo com que a averbação da área de reserva legal originária na matrícula do imóvel não fosse obrigatória, além da dispensabilidade de informações de dados da reserva ambiental ser prestada por meio de profissional legalmente habilitado, com validação do órgão ambiental.

Nesse sentido, percebe-se que apesar de conferir celeridade, a proteção do meio ambiente diminuiu com a desnecessidade de registro público da reserva ambiental. Tratase, portanto, de retrocesso e desrespeito ao Estado Democrático de Direito em razão da proteção ao meio ambiente integrar o conceito de propriedade.

\section{REFERÊNCIAS}

ALMEIDA, Ingrid Noetzold de. O Registro de Imóveis como instrumento de proteção socioambiental. Colégio Notarial do Brasil. Brasília: 2016. Disponível em: < http://www.notariado.org.br/index.php?pG=X19leGliZV9ub3RpY2lhcw==\&in=NjkwNw== $\&$ filtro=9\&Data=>.Acesso em: 22 maio 2016.

AYALA, Patryck de Araújo. Deveres ecológicos e regulamentação da atividade econômica na Constituição brasileira. In: CANOTILHO, José Joaquim Gomes; LEITE, José Rubens Morato (Org.). Direito Constitucional Ambiental Brasileiro. 5. ed. São Paulo: Saraiva, 2012.

BRASIL. Lei $\mathbf{n}^{\circ}$ 6.015, de 31 de dezembro de 1973. Dispõe sobre os registros públicos, e dá outras providências. Disponível em: <http://www.planalto.gov.br/ccivil_03/leis/L6015compilada.htm> Acesso em: 17 maio 2016.

BRASIL. Lei ${ }^{\circ}$ 6.938, de 31 de agosto de 1981. Dispõe sobre a Política Nacional do Meio Ambiente, seus fins e mecanismos de formulação e aplicação, e dá outras providências. Disponível em: <http://www.planalto.gov.br/ccivil_03/leis/L6938.htm>. Acesso em: 18 maio 2016. 
BRASIL. Constituição da República Federativa do Brasil de 1988. Disponível em: http://www.planalto.gov.br/ccivil_03/constituicao/constituicaocompilado.htm. Acesso em: 24 maio 2016

BRASIL. Lei $\mathbf{n}^{\mathbf{0}}$ 8.935, de 18 de novembro de 1994. Regulamenta o art. 236 da Constituição Federal, dispondo sobre serviços notariais e de registro. (Lei dos cartórios). Disponível em: <http://www.planalto.gov.br/ccivil_03/leis/L8935.htm> Acesso em: 24 maio 2016.

BRASIL. Lei no 10.406, de 10 de janeiro de 2002. Institui o Código Civil. Disponível em: <http://www.planalto.gov.br/ccivil_03/leis/2002/110406.htm> Acesso em: 25 maio 2016.

BRASIL. Lei $\mathbf{n}^{0}$ 12.651, de 25 de maio de 2012. Dispõe sobre a proteção da vegetação nativa. Disponível em: < http://www.planalto.gov.br/ccivil_03/_ato20112014/2012/lei/112651.htm> Acesso em: 25 maio 2016.

BRUSEKE, Franz. Josef. O Problema do Desenvolvimento Sustentável IN: INPSO/FUNDAJ, Instituto de Pesquisas Sociais, Fundação Joaquim Nabuco, Ministério de Educação, Governo Federal. Desenvolvimento e Natureza: Estudos para uma sociedade sustentável. Recife: p.29-40 1994.

CAMARGO, Flavia. Os rumos do cadastro ambiental precisam mudar. 2014. Disponível em: $\quad<$ http://www.socioambiental.org/pt-br/blog/blog-do-ppds/os-rumos-do-cadastroambiental-ruralcar-precisam-mudar>. Acesso em: 25 maio 2016.

CARVALHO, Carlos Gomes de. Introdução ao Direito Ambiental. São Paulo: Conceito, 2001.

CARVALHO FERNANDES, Luís A. Lições de direitos reais. 6 $6^{a}$ edição. Lisboa: Quide Juris, 2009.

CASTILHO, Marcela Cristina de. Direito de Propriedade e a Função Social. 2015. Disponível em: <http://mcristina.jusbrasil.com.br/artigos/146506494/direito-de-propriedadee-a-funcao-social>. Acesso em: 12 maio 2016.

CAVEDON, Fernanda de Salles. Função Social e Ambiental da Propriedade. Florianópolis: Visualbooks, 2003.

D’ÁVILA, Gilmara Vanderlinde Medeiros. Averbação da reserva legal x Cadastro ambiental rural, avanço ou retrocesso?. Revista Eletrônica Direito e Política. Itajaí: v.10, n.1, edição especial de 2015.20 Disponível em: <http://siaiap32.univali.br/seer/index.php/rdp/article/viewFile/7173/4072>. Acesso em: 20 maio 2016. 
DELLAZARI, Juliana Cristina. Áreas de preservação permanente e reserva legal. 2012. Disponível em: http://www.buscalegis.ufsc.br/revistas/files/anexos/26598-26600-1PB.htm>. Acesso em: 08 maio 2016.

FENSTERSEIFER, Tiago. Direitos fundamentais e proteção do ambiente: a dimensão ecológica da dignidade humana no marco jurídico constitucional do estado socioambiental de direito. Porto Alegre: Livraria do Advogado Editora, 2008, p. 159.

FERNANDES, Edésio. A nova ordem jurídico-urbanística do Brasil. Belo Horizonte: Del Rey, 2006.

HARADA, Kyoshi. Desapropriação - Doutrina e prática. 6. Ed. São Paulo: Atlas, 2006.

HELLSTROM, Luciano. O Registro de Imóveis como um instrumento de fiscalização de Meio Ambiente. 2016. Disponível em: $<$ http://hellstrom.jusbrasil.com.br/artigos/325838251/o-registro-de-imoveis-como-uminstrumento-de-fiscalizacao-de-meio-ambiente>.Acesso em: 22 maio 2016.

LAGO, André Aranha Corrêa do. Estocolmo, Rio, Joanesburgo: o Brasil e a três conferências ambientais das Nações Unidas. Brasília: Thesaurus Editora, 2007.

LOUREIRO, Luiz Guilherme. Registros Públicos: Teoria e Prática. 5. ed. São Paulo: Metodo, 2014.

MACHADO, Paulo Affonso Leme. Direito Ambiental Brasileiro. $18^{\mathrm{a}}$ ed. São Paulo, Malheiros, 2010.

MARÉS, Carlos Frederico. A função social da terra. Porto Alegre: Fabris, 2003.

MELO, Marcelo Augusto Santana de. Breves anotações sobre o Registro de Imóveis. Jus Navigandi, Teresina, ano 8, n. 429, 2004. Disponível em: <http://www1.jus.com.br/doutrina/texto.asp?id=5669\&gt>.Acesso em: 19 maio 2016.

MELO, Marcelo Augusto Santana de. Meio ambiente e o Registro de Imóveis. Coordenadores. Marcelo Augusto Santana de Melo, Francisco de Asis Palácios Criado e Sérgio Jacomino. São Paulo. Ed. Saraiva: 2010. Disponível em: <https://marcelommmelo.com/obra-meio-ambiente-e-registro-de-imveis-2/\#_ftnref11>. Acesso em: 23 maio 2016.

MILARÉ, Edis. Direito do ambiente. São Paulo: Revista dos Tribunais, 2005.

SILVA, José Afonso da. Direito Ambiental. 2a ed. São Paulo: Malheiros, 1998.

PORTO-GONÇALVES, Carlos Walter. A globalização da natureza e a natureza da globalização. Rio de Janeiro: Editora José Olympio, 2015. 
RENAN, Mariana de Paula e Souza. O potencial do cadastro ambiental rural - CAR como instrumento de regularização ambiental no Estado de Minas Gerais. 2015. Dissertação (Mestrado em Direito) Escola Superior Dom Helder Câmara: Belo Horizonte: 2015. Disponível

em: <http://domhelder.edu.br/mestrado/editor/assets/arquivos_dissertacoesdefendidas/7f80fbace0e f2a1c20f5975342e3bbe6.pdf Acesso em: 01 jun. 2016.

SANTOS, Orlando Rey. El desarrollo del constitucionalismo ambiental en América Latina. Programa Regional de Capacitación en Derecho y Políticas Ambientales. 2008. Disponível em: <http://web.pnuma.org/gobernanza/documentos/VIProgramaRegional/9a\%20PERS\%20SEC \%20REG\%20Y\%20LOC\%20PARA\%20DER\%20AMB/38\%20Rey\%20Santos\%20Desarroll o\%20del\%20constitucionalismo\%20ambiental.pdf>. Acesso em: 20 maio 2016.

SILVA, José Afonso da. Direito Ambiental Constitucional. 9. Ed. São Paulo, Malheiros Editores, 2011.

SANTOS, Marcos Alberto Pereira. Dispensa da averbação da reserva legal no novo Código Florestal. In: Âmbito Jurídico. Rio Grande: n. 103, 2012. Disponível em: <http://www.ambito-juridico.com.br/site/?n_link=revista_artigos_leitura\&artigo_id=11862> . Acesso em: 02 jun. 2016.

THOMÉ, Romeu. O princípio da vedação de retrocesso socioambiental no contexto da sociedade de risco. Salvador: Juspodivm, 2014.

WEBER, Cristiano. A política ambiental e criminal no estado ambiental. In: Revista Veredas do Direito. Belo Horizonte: v.11, n.22, p.113-142, Jul./Dez. 2014. 